\title{
Letter
}

\section{The Risk of Diabetes on Clinical Outcomes in Patients with Coronavirus Disease 2019: A Retrospective Cohort Study (Diabetes Metab J 2020;44:405-13)}

\author{
So-Yeon Kim, Kyung-Soo Kim \\ Department of Internal Medicine, CHA Bundang Medical Center, CHA University School of Medicine, Seongnam, Korea
}

We are living in the coronavirus disease 2019 (COVID-19) pandemic era. In December 2019, COVID-19 started in Wuhan, China, and it has now become a global health concern. COVID-19 was detected as pneumonia of an unknown cause in the early days, and it turned out to be caused by the severe acute respiratory syndrome coronavirus 2 (SARS-CoV-2) $[1,2]$. The SARS-CoV-2 is readily transmitted from person-toperson, even by those who are infected but without symptoms [2]. As of 15 June 2020, a total of 7,838,530 COVID-19 cases were confirmed all over the world, and 432,467 patients had died [3]. Many studies have noted that older people and those with underlying medical conditions are more vulnerable to COVID-19 [4,5]. Especially in patients with diabetes mellitus (DM), clinicians should pay attention to prevent COVID-19 because $\mathrm{DM}$ is one of the conditions associated with high morbidity and mortality risk $[5,6]$.

In this article entitled, "The risk of diabetes on clinical outcomes in patients with coronavirus disease 2019: a retrospective cohort study," Chung et al. [7] explored the clinical characteristics of COVID-19 patients with DM and compared risk factor such as age, glycemic control, and medications to patients without DM. Among 110 participants, COVID-19 patients with DM had a higher rate of severe outcomes, including 28-day mortality, than those without DM. After adjustment for other risk factors, the risk of severe and critical outcomes (SCO) was 10 times higher in patients with DM than in those without DM. In patients with DM, old age was an independent risk factor for SCO in COVID-19, but glycemic control was not. Interestingly, the use of medication and poor glycemic control did not affect the SCO in COVID-19 patients. However, there are several issues to be discussed.

First, the result of this study was consistent with previous studies that patients with DM are vulnerable to COVID-19 and show poor prognosis. Furthermore, several studies have found that diabetes control has a role to play in COVID-19 outcomes $[8,9]$. In this study, however, poor glycemic control (glycosylated hemoglobin $\geq 8 \%$ ) did not affect the prognosis of COVID-19 patients. The causal mechanism behind correlations between glucose control and worse COVID-19 outcomes is unclear because worse infection may predispose clinicians to more difficulty managing patient blood glucose.

Second, there has been some discussion regarding use of angiotensin-converting enzyme (ACE) inhibitors and angiotensin receptor blockers (ARBs) being associated with worse outcomes in COVID-19 patients, particularly in patients with DM $[10,11]$. Although ACE inhibitors and ARBs seem to increase the number of ACE2 receptors on the cells utilized by SARSCoV-2 for penetration, no evidence presently exists that shows this might be harmful in terms of acquiring or worsening COVID-19 $[12,13]$. Rather, in this study, the renin-angiotensin system inhibitors showed protective effects against acute cardiac injury. To date, in view of data showing potential benefits, 
the current recommendation is to continue with these therapies [6].

Finally, increased age is strongly associated with increased risks for COVID-19 severity [5]. In this study, SCO was more prevalent in elderly patients $\geq 70$ years old and age was an independent risk factor for SCO in patients with DM. Special attention is needed to prevent and treat COVID-19 infection in elderly patients with DM.

\section{CONFLICTS OF INTEREST}

No potential conflict of interest relevant to this article was reported.

\section{REFERENCES}

1. Zhou F, Yu T, Du R, Fan G, Liu Y, Liu Z, Xiang J, Wang Y, Song B, Gu X, Guan L, Wei Y, Li H, Wu X, Xu J, Tu S, Zhang Y, Chen $\mathrm{H}$, Cao B. Clinical course and risk factors for mortality of adult inpatients with COVID-19 in Wuhan, China: a retrospective cohort study. Lancet 2020;395:1054-62.

2. Chan JF, Yuan S, Kok KH, To KK, Chu H, Yang J, Xing F, Liu J, Yip CC, Poon RW, Tsoi HW, Lo SK, Chan KH, Poon VK, Chan WM, Ip JD, Cai JP, Cheng VC, Chen H, Hui CK, Yuen KY. A familial cluster of pneumonia associated with the 2019 novel coronavirus indicating person-to-person transmission: a study of a family cluster. Lancet 2020;395:514-23.

3. Ministry of Health and Welfare, Republic of Korea: Global locations with COVID-19. Available from: http://ncov.mohw. go.kr/en/bdBoardList.do?brdId=16\&brdGubun=163\&dataGu bun=\&ncvContSeq=\&contSeq=\&board_id= (cited 2020 Jul 8).

4. Guan WJ, Ni ZY, Hu Y, Liang WH, Ou CQ, He JX, Liu L, Shan H, Lei CL, Hui DSC, Du B, Li LJ, Zeng G, Yuen KY, Chen RC, Tang CL, Wang T, Chen PY, Xiang J, Li SY, Wang JL, Liang ZJ, Peng YX, Wei L, Liu Y, Hu YH, Peng P, Wang JM, Liu JY, Chen Z, Li G, Zheng ZJ, Qiu SQ, Luo J, Ye CJ, Zhu SY, Zhong NS; China Medical Treatment Expert Group for Covid-19. Clinical characteristics of coronavirus disease 2019 in China. N Engl J Med 2020;382:1708-20.

5. Riddle MC, Buse JB, Franks PW, Knowler WC, Ratner RE, Selvin E, Wexler DJ, Kahn SE. COVID-19 in people with diabetes: urgently needed lessons from early reports. Diabetes Care 2020;43:1378-81.

6. Ceriello A, Standl E, Catrinoiu D, Itzhak B, Lalic NM, Rahelic D, Schnell O, Skrha J, Valensi P; Diabetes and Cardiovascular Disease (D\&CVD) EASD Study Group. Issues of cardiovascular risk management in people with diabetes in the COVID-19 era. Diabetes Care 2020;43:1427-32.

7. Chung SM, Lee YY, Ha E, Yoon JS, Won KC, Lee HW, Hur J, Hong KS, Jang JG, Jin HJ, Choi EY, Shin KC, Chung JH, Lee $\mathrm{KH}, \mathrm{Ahn} \mathrm{JH}$, Moon JS. The risk of diabetes on clinical outcomes in patients with coronavirus disease 2019: a retrospective cohort study. Diabetes Metab J 2020;44:405-13.

8. Ceriello A, Zarich SW, Testa R. Lowering glucose to prevent adverse cardiovascular outcomes in a critical care setting. J Am Coll Cardiol 2009;53(5 Suppl):S9-13.

9. Bode B, Garrett V, Messler J, McFarland R, Crowe J, Booth R, Klonoff DC. Glycemic characteristics and clinical outcomes of COVID-19 patients hospitalized in the United States. J Diabetes Sci Technol 2020;14:813-21.

10. South AM, Tomlinson L, Edmonston D, Hiremath S, Sparks MA. Controversies of renin-angiotensin system inhibition during the COVID-19 pandemic. Nat Rev Nephrol 2020;16:305-7.

11. Fang L, Karakiulakis G, Roth M. Are patients with hypertension and diabetes mellitus at increased risk for COVID-19 infection? Lancet Respir Med 2020;8:e21.

12. Chen Y, Yang D, Cheng B, Chen J, Peng A, Yang C, Liu C, Xiong M, Deng A, Zhang Y, Zheng L, Huang K. Clinical characteristics and outcomes of patients with diabetes and COVID-19 in association with glucose-lowering medication. Diabetes Care 2020;43:1399-407.

13. Zhang P, Zhu L, Cai J, Lei F, Qin JJ, Xie J, Liu YM, Zhao YC, Huang X, Lin L, Xia M, Chen MM, Cheng X, Zhang X, Guo D, Peng Y, Ji YX, Chen J, She ZG, Wang Y, Xu Q, Tan R, Wang H, Lin J, Luo P, Fu S, Cai H, Ye P, Xiao B, Mao W, Liu L, Yan Y, Liu M, Chen M, Zhang XJ, Wang X, Touyz RM, Xia J, Zhang BH, Huang X, Yuan Y, Rohit L, Liu PP, Li H. Association of inpatient use of angiotensin-converting enzyme inhibitors and angiotensin ii receptor blockers with mortality among patients with hypertension hospitalized with COVID-19. Circ Res 2020;126: 1671-81. 